\title{
EFFICIENCY OF NATURAL AND ARTIFICIAL OIL SORBENTS
}

\author{
Glibovytska N.I., Plaksiy L.V. \\ Ivano-Frankivsk National Technical University of Oil and Gas, \\ Karpatska street, 19, 76000, Ivano-Frankivsk \\ nataly.glibovytska@gmail.com
}

\begin{abstract}
The prospect of using the most widespread in the industry and national economy natural and synthetic materials in the purification of the environment from oil is considered. The maximum absorption capacity of cotton as a natural material is identified, that quickly absorbs oil components and does not require the use of additional resources to combat water contamination. It is found that natural charcoal absorbent is inefficient in comparison with other methods of water purification from oil and requires a long time and additional pollution catchers, which is economically unprofitable. Synthetic polymer foam and white coal absorb oil in a short time, but in the latter case, nevertheless, small spots remain on the surface of the water. According to the efficiency of oil absorption by natural and synthetic materials, we can distinguish the following series of investigated materials: black coal $\rightarrow$ foam $\rightarrow$ white coal $\rightarrow$ cotton. Key words: oil, pollution, water resources, purification, methods, sorbents.
\end{abstract}

Ефективність природних і штучних сорбентів нафти. Глібовицька Н.І., Плаксій Л.В. У статті розглянуто перспективність використання найпоширеніших у промисловості й народному господарстві природних і синтетичних матеріалів в очищенні довкілля від нафти. Виявлено максимальну поглинальну здатність бавовни як природного матеріалу, який швидко абсорбує компоненти нафти й не вимагає використання додаткових ресурсів для боротьби з контамінацією води. 3'ясовано, що природній абсорбент чорне вугілля малоефективне порівняно з іншими методами очищення води від нафти та вимагає тривалого часу й додаткових уловлювачів забруднення, що є економічно невигідним. Синтетичний полімер пінопласт і біле вугілля поглинають нафту за короткий час, однак в останньому випадку на поверхні води залишаються незначні плями. За ефективністю поглинання нафти природними та синтетичними матеріалами можна виділити такий ряд досліджених матеріалів: чорне вугілля $\rightarrow$ пінопласт $\rightarrow$ біле вугілля $\rightarrow$ бавовна. Ключові слова: нафта, забруднення, водні ресурси, очищення, методи, сорбенти.

\begin{abstract}
Эффективность естественных и искусственных сорбентов нефти. Глибовицкая Н.И., Плаксий Л.В. В статье рассмотрена перспективность использования самых распространенных в промышленности и народном хозяйстве природных и синтетических материалов в очистке окружающей среды от нефти. Выявлена максимальная поглощающая способность хлопка как природного материала, который быстро абсорбирует компоненты нефти и не требует использования дополнительных ресурсов для борьбы с контаминацией воды. Выяснено, что естественный абсорбент черный уголь малоэффективен по сравнению с другими методами очистки воды от нефти и требует длительного времени и дополнительных ловушек загрязнения, что экономически невыгодно. Синтетический полимер пенопласт и белый уголь поглощают нефть за короткое время, однако в последнем случае на поверхности воды остаются незначительные пятна. По эффективности поглощения нефти естественными и синтетическими материалами можно выделить следующий ряд исследованных материалов: черный уголь $\rightarrow$ пенопласт $\rightarrow$ белый уголь $\rightarrow$ хлопок. Ключевые слова: нефть, загрязнение, водные ресурсы, очистка, методы, сорбенты.
\end{abstract}

Formulation of the problem. Oil is one of the main and most dangerous pollutants in water ecosystems, which leads to the death of their inhabitants. Each year more than 3 million tons of oil comes into the water areas of the seas and oceans as a result of accidents on drilling rigs and platforms, mainly on gas and oil pipelines. Construction and technological defects and corrosion of the pipelines lead to breakthrough and destruction of equipment with the subsequent emergency oil spill (V.F. Kablov, Yu.P. Ioschenko, 2004; V.A. Vladimirov, 2014)

On the water surface oil can form a film, be in the form of substances dissolved or emulsified in water, or settle down to the bottom of the reservoir. Toxic influence of oil components on water inhabitants leads to their death and poisoning of organisms that are at the higher trophic levels of the food pyramid. Low molecular weight aliphatic, naphthenic, aromatic hydrocarbons, as well as heavy metals present in oil are harmful to the circulatory, nervous systems of a man (L.V. Plaksiy, 2016). That is why the search of ways to defeat the problem of environmental oil pollution is very important.

Connection of the author's work with important scientific and practical tasks. The highest levels of oil pollution are observed in the Mediterranean and the Baltic seas, respectively, 17 and $14 \%$ of all pollution of the world's oceans. The highest concentrations of oil are recorded mainly in the water surface, bottom layer and in the coastal zone. The main components of oil hydrocarbons of various classes - have low solubility in water, which decreases with an increase in the length of the carbon chain in their molecules (N.N. Brakorenko, T.V. Korotchenko, 2016).

As an insoluble in water mixture, the oil forms an emulsion of the next types - "oil in water" and "water in oil". Particular hazards are aggregates - oil lumps in 
the size of 1-20 $\mathrm{mm}$ - since they can be stored for a long time in water, move the flow and settle on the bottom of the reservoir. The aggregates are formed as a result of the combination of high molecular weight hydrocarbons such as resins and asphaltenes in a single mixture that is a trap for water inhabitants - invertebrates and lower plants (M.R. Tsibulnikova et al., 2015).

In Ukraine, where more than 0.5 million tons of oil comes into the aquatic ecosystems every year, the following gradation to determine the mass of oil on the surface of the water is used (Table 1) (V. Maksimov, 2004).

Analysis of recent researches and publications. To combat oil pollution, the following methods are used (O.V. Pogharnitskaya et al., 2016; N.I. Glibovytska, L.V. Plaksiy, 2018):

- mechanical - use of equipment, in particular separators, for the purification of oil-contaminated water;

- biological - decomposition of petroleum products by microorganisms of Calanus, Penicillium, Candida types, capable to metabolizing toxic components of oil and detoxifying them to harmless compounds. This method, also known as bioremediation, is environmentally safe and can be used to restore the abiotic medium transformed under the influence of oil (T.M. Yatsyshyn, N.I. Glibovytska, 2016);

- dispersant - the use of dispersants brands DN-75 and EPN-5, which emulsify the oil film to individual droplets, subjected to further biochemical decomposition;

- sorption - is the use of natural or synthetic porous materials that can effectively absorb oil - coal, perlite, wood sawdust, bentonite clay, cotton, peat, polystyrene, foam, aluminosilicates, sapropel.

Relevance of research. It is the sorbent method that is one of the most promising ways to clean water-contaminated water, since it is least cost-effective and fastest in dealing with pollution problems compared to others. Therefore, the purpose of this work is to assess the effectiveness of natural and artificial sorbent materials in purifying water from oil pollution.

The allocation of previously unsettled parts of the general problem to which this article is devoted. Among all the methods known today for purifying the environment from oil, the sorption method is least studied. Therefore, analysis of materials' properties that would help to cope with environmental oil pollution is extremely important. The problem of methods combating the oil contamination of natural resources lies in their expensiveness and labor-intensiveness. Each method has both advantages and disadvantages, but the first reason to choose the method is its environmental safety. In this context, there is a wide range of substances that possess adsorbing properties, help to get rid of pollution of various origins. Therefore studies of oil absorption by materials, widely used in everyday life and in various areas of industry, are of great practical importance.

Novelty. For the first time, the comparative effectiveness of simple and affordable natural and artificial materials that can be used as adsorbents of oil in the case of its entry into water resources is evaluated. These economically advantageous and low-cost products do not pollute the environment, do not threaten the safety of living organisms and quickly cope with this problem.

Methodological or general scientific significance. Under laboratory conditions an oil was added to the water with the aid of a dispenser and formed an oil spot with a diameter of $50-70 \mathrm{~mm}$ on the surface of the water. The sorbent was added to the surface in an amount that would provide a full coverage of the formed spot and the time of the oil absorption was determined. The repetition of the experiment is threefold.

As sorbents, foam, cotton, white and black coal were used.

Cotton today is one of the main types of raw materials of the textile industry. This natural material is extracted from an annual bush plant - cotton. By chemical composition $95 \%$ of cotton consists of cellulose, and also contains a small amount of natural waxes, proteins and neutral fats. Cotton fibers are characterized by durability, flexibility, softness, clarity, heat-shielding properties.

Polyfoam is a synthetic material with a porous structure, obtained by foaming polystyrene granules. It is characterized by low density, high thermal insulation characteristics. Polyfoam has advantages over other artificial materials used in different branches of industry.

Visual indicators for determining the oil mass on the water surface

Table 1

\begin{tabular}{|c|l|c|}
\hline \multicolumn{1}{|c|}{$\begin{array}{c}\text { Determination of the mass of oil per } \mathbf{1} \mathbf{~ m}^{\mathbf{2}} \text { of water surface } \\
\text { on the appearance of film oil (average data) }\end{array}$} & $\begin{array}{c}\text { Mass of oil per 1 } \mathbf{~ m}^{\mathbf{2}} \\
\text { of water surface (g) }\end{array}$ \\
\hline 1 & Pure water surface without signs of coloring under various lighting conditions & 0 \\
\hline 2 & $\begin{array}{l}\text { Lack of film and stains, individual rainbow strips, which can be seen under the } \\
\text { most favorable conditions and calm condition of the water surface. }\end{array}$ & 0,1 \\
\hline 3 & $\begin{array}{l}\text { Separate stains and gray films of silver on the surface of the water, which are } \\
\text { visible at a calm condition of the water surface, the appearance of the first signs } \\
\text { of coloration }\end{array}$ & 0,2 \\
\hline 4 & Spots and films with bright colored stripes that can be seen with minor waving & 0,4 \\
\hline 5 & $\begin{array}{l}\text { Oil in the form of spots and films that cover significant areas of the surface of the } \\
\text { water that do not burst during agitation }\end{array}$ & 1,2 \\
\hline 6 & $\begin{array}{l}\text { The surface of the water is covered with a solid layer of oil, well visible in waving, } \\
\text { the color is dark, dark brown }\end{array}$ & 1,5 \\
\hline
\end{tabular}


Features of the oil absorption by sorbents

\begin{tabular}{|c|c|c|c|c|c|c|c|}
\hline \multirow{2}{*}{ № } & \multirow{2}{*}{$\begin{array}{c}\text { Type of } \\
\text { sorbent }\end{array}$} & $\begin{array}{c}\text { Experiment 1 } \\
\text { The time } \\
\text { of sorption, } \\
\text { sec. }\end{array}$ & $\begin{array}{c}\text { The spot } \\
\text { diameter, } \\
\text { cm }\end{array}$ & $\begin{array}{c}\text { The time } \\
\text { of sorption, } \\
\text { sec. }\end{array}$ & $\begin{array}{c}\text { The spot } \\
\text { diameter, } \\
\text { cm }\end{array}$ & $\begin{array}{c}\text { The time } \\
\text { of sorption, } \\
\text { sec. }\end{array}$ & $\begin{array}{c}\text { The spot diam- } \\
\text { eter, } \\
\text { cm }\end{array}$ \\
\hline 1 & Black coal & 8.26 & 5.0 & 9.12 & 6.5 & 8.45 & 5.7 \\
\hline 2 & White coal & 3.02 & 5.3 & 1.56 & 5.5 & 1.76 & 5.4 \\
\hline 3 & Polyfoam & 6.26 & 5.1 & 3.56 & 7.0 & 5.22 & 5.3 \\
\hline 4 & Cotton & 1.49 & 5.5 & 0.18 & 5.5 & 1.48 & 5.4 \\
\hline
\end{tabular}

One of the advantages is its waterproofness, which is especially important in case of its application in the fight against oil pollution. Another advantage is the low cost of raw materials and foam production technology.

Black coal is a natural substance with a porous carbon structure with high adsorption properties and hydrophobicity. Due to its effective absorbing properties, black coal is widely used in medicine, chemistry, food industry and everyday life.

White coal - a natural inorganic substance - silicon dioxide - has a high dispersion and sorption properties. The commercial name "white coal" the preparation received by analogy with black coals due to known sorption characteristics, but its composition does not contain coal. Sorbent properties of white coal significantly exceed the same indicators for black coal. However, whether this property of white coal allows us to cope better with oil pollution, the experiment has shown.

Presentation of the main material. In the case of the use of black coal, there is a process of thickening of the oil spill (Table 2). The process of sorption is slow, part of the sorbent with sorbed petroleum products formed a precipitate.

As a result of the use of white coal, the process of thickening of the oil spot takes place quite intensively. The big part of the sorbent that entered the reaction fell into the precipitate.

In the case of foam there is a process of adhesion (sticking to the bottom of the foam). Oil is closely linked with foam, which indicates the passage of the process of sorption (absorption) of oil.

As a result of the use of cotton as a sorbent, the process of adhesion is observed when the oil spot adheres very quickly to the surface, after which it is possible to separate water pollution easily.

Main conclusions and prospects for using research results. According to the type of sorbent used to clean water from oil pollution, the time and quality of oil absorption depends.

Experimental research has shown that cotton is the most optimal option for water purification from oil. In this case, it is not necessary to use additional sediment traps. Cotton is the fastest way to absorb oil. The water remains clean as a result. This is the fastest and most effective way.

Absorption of oil by white coal is carried out in a small amount of time, part of the sorbent falls into the precipitate. Since not all of the mass of white coal has come into contact with oil, on the surface partly there are minor spots.

Polyfoam absorbs oil in a short time, but inferior to the efficiency of absorption of white coal and cotton natural materials.

Absorption of oil by black coal requires a considerable amount of time and traps, since coal is largely dispersed and quickly precipitates. This method of purifying water from oil is most economically disadvantageous and requires more time to reach the goal.

\section{References}

1. Brakorenko N.N., Korotchenko T.V. Impact of petroleum products on soil composition and physical-chemical properties. IOP Conf. Series: Earth and Environmental Science. 2016. № 33. H. 1-6. doi:10.1088/1755-1315/33/1/012028.

2. Glibovytska N.I., Plaksiy L.V. Methods of water treatment from oil contamination. Ecological education and ecological culture of the population: materials of the VI international scientific conference on February 25-26, 2018. Prague. P. 44-45.

3. Kablov V.F., Ioschenko Yu.P. Oil spills and the issue of oil removal. Fundamental Research. 2004. № 6. P. 64.

4. Maksimov V., Dinyak S., Dinyak O. Analysis of systemic losses of petroleum products at enterprises of oil and gas complex of Ukraine. Ecology of environment and life safety. 2004. № 5. P. 41-44.

5. Plaksiy L.V. Methodology of estimation of surface water in the places of influence of objects of oil pipeline transport. Ecological safety and balanced resource use. Ivano-Frankivsk: IFNTUNG, 2016. № 2 (14). 5 p.

6. Pogharnitskaya O.V. et al. Treatment of petroleum-contaminated water resources: modern techniques. IOP Conf. Series: Earth and Environmental Science. 2016. № 43. P. 1-6. doi.org/10.1088/1755-1315/43/1/012026.

7. Tsibulnikova M.R. et al. Economic assessment of environmental impact in the course of oil field development and production. IOP Conf. Series: Earth and Environmental Science. 2015. № 27. P. 1-5. doi:10.1088/1755-1315/27/1/012076.

8. Vladimirov V.A. Oil spills: causes, scales, effects. Civil safety strategy: issues and research. 2014. № 1. 217 p.

9. Yatsyshyn T.M., Glibovytska N.I. Influence of oil and gas extraction on the environment and prospects of phytodynamics and phytothermization of technogenotransformed territories. Ecological safety and balanced resource use. 2016. № 1. P. $22-29$. 